\title{
Process Development for Newcastle Disease Virus-Vectored Vaccines in Serum-Free Vero Cell Suspension Cultures
}

\author{
Julia Puppin Chaves Fulber ${ }^{1}{ }^{\circledR}$, Omar Farnós ${ }^{1} \mathbb{D}$, Sascha Kiesslich ${ }^{1}$, Zeyu Yang ${ }^{1}{ }^{\circledR}$, Shantoshini Dash ${ }^{1}$, \\ Leonardo Susta $^{2}\left(\mathbb{D}\right.$, Sarah K. Wootton ${ }^{2}(\mathbb{D})$ and Amine A. Kamen 1,*(D) \\ 1 Viral Vectors and Vaccines Bioprocessing Group, Department of Bioengineering, McGill University, \\ Montreal, QC H3A 0G4, Canada; julia.puppinchavesfulber@mail.mcgill.ca (J.P.C.F.); \\ omar.farnosvillar@mcgill.ca (O.F.); sascha.kiesslich@mail.mcgill.ca (S.K.); zeyu.yang2@mcgill.ca (Z.Y.); \\ shantoshini.dash@mail.mcgill.ca (S.D.) \\ 2 Department of Pathobiology, Ontario Veterinary College, University of Guelph, \\ Guelph, ON N1G 2W1, Canada; 1susta@uoguelph.ca (L.S.); kwootton@uoguelph.ca (S.K.W.) \\ * Correspondence: amine.kamen@mcgill.ca
}

check for updates

Citation: Fulber, J.P.C.; Farnós, O.; Kiesslich, S.; Yang, Z.; Dash, S.; Susta, L.; Wootton, S.K.; Kamen, A.A. Process Development for Newcastle Disease Virus-Vectored Vaccines in Serum-Free Vero Cell Suspension Cultures. Vaccines 2021, 9, 1335. https://doi.org/10.3390/

vaccines 9111335

Academic Editor: Antonella Caputo

Received: 19 October 2021

Accepted: 12 November 2021

Published: 16 November 2021

Publisher's Note: MDPI stays neutral with regard to jurisdictional claims in published maps and institutional affiliations.

Copyright: (C) 2021 by the authors. Licensee MDPI, Basel, Switzerland. This article is an open access article distributed under the terms and conditions of the Creative Commons Attribution (CC BY) license (https:/ / creativecommons.org/licenses/by/ $4.0 /)$.

\begin{abstract}
The ongoing COVID-19 pandemic drew global attention to infectious diseases, attracting numerous resources for development of pandemic preparedness plans and vaccine platformstechnologies with robust manufacturing processes that can quickly be pivoted to target emerging diseases. Newcastle Disease Virus (NDV) has been studied as a viral vector for human and veterinary vaccines, but its production relies heavily on embryonated chicken eggs, with very few studies producing NDV in cell culture. Here, NDV is produced in suspension Vero cells, and analytical assays (TCID 50 and ddPCR) are developed to quantify infectious and total viral titer. NDV-GFP and NDV-FLS (SARS-CoV-2 full-length spike protein) constructs were adapted to replicate in Vero and HEK293 suspension cultures using serum-free media, while fine-tuning parameters such as MOI, temperature, and trypsin concentration. Shake flask productions with Vero cells resulted in infectious titers of $1.07 \times 10^{8} \mathrm{TCID}_{50} / \mathrm{mL}$ for NDV-GFP and $1.33 \times 10^{8} \mathrm{TCID}_{50} / \mathrm{mL}$ for NDV-FLS. Production in $1 \mathrm{~L}$ batch bioreactors also resulted in high titers in culture supernatants, reaching $2.37 \times 10^{8} \mathrm{TCID}_{50} / \mathrm{mL}$ for NDV-GFP and $3.16 \times 10^{7} \mathrm{TCID}_{50} / \mathrm{mL}$ for NDV-FLS. This shows effective NDV production in cell culture, building the basis for a scalable vectored-vaccine manufacturing process that can be applied to different targets.
\end{abstract}

Keywords: Newcastle Disease Virus; Vero suspension culture; viral vaccine bioprocess; bioreactor production; vaccine production platform; COVID-19; SARS-CoV-2

\section{Introduction}

Infectious diseases are present throughout history, emerging and reemerging as decades pass [1]. In the most recent years, the world has seen outbreaks of H1N1 influenza, severe acute respiratory syndrome coronavirus (SARS-CoV), human immunodeficiency virus (HIV) [2] and, notably, SARS-CoV-2 [3]. Vaccines have been a key player in containing the spread and reducing the mortality of bacterial and viral pathogens, taking part in national and global immunization strategies that have led to eradication of smallpox and near eradication of polio [4].

Recombinant viral vectors have become an important platform for vaccination, with growing interest in a variety of possible vectors. Viral vector vaccines have been approved against Ebola [5] — using adenovirus [6], modified Vaccinia Ankara [7,8], and vesicular stomatitis virus [9] as vectors-and against SARS-CoV-2, using adenovirus as a vector (Johnson \& Johnson, Gamaleya, Oxford-Astrazeneca and CanSino) [1,10]. There are also examples of approved viral vector vaccines for veterinary use, using vectors such as poxviruses, herpesvirus of turkeys (HVT) [11] and adenovirus [12,13]. This technology fits the concept of platform-based vaccines, in which the viral vector is a backbone that can be 
modified to express and carry different antigens to quickly adapt the vaccine to target other pathogens, including for emerging outbreaks. By developing a platform-based vaccine and establishing a production process for it, both the product and process can be adapted to other targets with minimal changes. Thus, the time to develop, scale up and, consequently, deliver the vaccine can be greatly reduced, making this a promising approach for pandemic preparedness [14].

In this context, the Newcastle Disease Virus (NDV) is an avian paramyxovirus which is non-pathogenic in humans [2]. NDV is classified into three types of strains: velogenic, mesogenic or lentogenic, based on virulence and pathogenicity in avian species [15]. Lentogenic strains, such as LaSota and B1, are avirulent in both birds and humans, making them the strains of choice for viral vector studies. NDV expresses a fusion protein (F) in its precursor form $\left(\mathrm{F}_{0}\right)$, which must be cleaved by host cell proteases for viral entry [2]. In cell culture, trypsin can be added at the moment of infection to activate the virus [16], as it is done for production of influenza [17]. As an avian virus, there is a lack of pre-existing immunity against NDV among humans, as well as remarkable safety, which has been documented in clinical trials for oncolytic treatments using this virus [2]. Another advantage of using this vector for vaccines includes operation at biosafety level 2, rather than working directly with the target pathogens, which can require costly operation at biosafety level 3 [18]. Additionally, there are well established methods to generate recombinant NDV constructs bearing protective key antigens from other viral pathogens. These aspects make NDV a promising vaccine vector that has already been explored in vaccine candidates against H1N1 influenza, SARS-CoV, HIV, among others [2].

Despite having garnered interest as a viral vector for vaccination and for cancer therapy [15], there are still few studies on the development of production processes for NDV. Typically, this virus is produced in embryonated chicken eggs and collected in the allantoic fluid. Although this is a cost-effective method that can take advantage of existing manufacturing structures for influenza [18], it also presents disadvantages when compared to cell culture technologies and their potential large-scale production under controlled operational conditions in bioreactors. Virus production in cell culture allows for greater control over several parameters, leading to less variation between batches and the capacity to further optimize each aspect. It may also avoid issues with allergens and the dependency on chicken egg supply $[19,20]$. As such, developing a cell culture-based NDV production process would be highly valuable in the pursuit of establishing a reliable vaccine production platform that allows for quick adaptation to emerging pathogens.

The COVID-19 pandemic highlighted the importance of mass vaccination and the race for fast implementation. Notably, vaccines were developed and approved within months, rather than the usual timespan of years [3], which was partly due to extensive previous research on the technologies used. These vaccines were key to reduce cases and deaths [21], as well as to recover economies [22], in contrast to the $2009 \mathrm{H} 1 \mathrm{~N} 1$ pandemic, in which vaccines were only widely available after the main onset of the pandemic [23]. This further showcases the importance of using vaccine platforms to implement vaccination early on in a pandemic, maximizing the positive contribution of vaccines and avoiding the peak of cases and deaths.

In this work, we set out to develop a novel cell-based production process for two NDV constructs: NDV-GFP and the vaccine candidate NDV-FLS, which expresses the full-length SARS-CoV-2 spike protein. We first adapted both constructs to HEK293 and Vero cells, and then evaluated several infection parameters. In shake flasks, viral production kinetics were compared for different multiplicities of infection (MOI) and a Design of Experiment (DoE) was performed to analyze the effects of temperature, trypsin concentration and trypsin addition. The best conditions were then implemented for batch bioreactor productions of both viruses. For the analytics, we established two assays for viral quantification: median tissue culture infectious dose $\left(\mathrm{TCID}_{50}\right)$ for infectious viral titer and digital droplet PCR (ddPCR) for genomic/total viral titer. As such, this is an innovative work in exploring and 
establishing these essential aspects for robust production and quality assessments of NDV in cell culture.

\section{Materials and Methods}

\subsection{Cell Lines and Culture Media}

The Vero cell line adapted to suspension was provided by the National Research Council of Canada (NRC), and the adaptation was described in a previous work [24]. For routine passaging, cells were centrifuged at $800 \times g$ for $5 \mathrm{~min}$ and resuspended in fresh media with a seeding density of 3-6 $\times 10^{5}$ cells $/ \mathrm{mL}$. Cell cultures were maintained at $37^{\circ} \mathrm{C}, 135 \mathrm{rpm}$ and $5 \% \mathrm{CO}_{2}$ in humified Multitron orbital shakers (Infors HT, Bottmingen, Switzerland). Cells were cultured in MDXK medium (Xell AG, Bielefeld, Germany), supplemented with 4 mM GlutaMAX (Thermo Fisher Scientific, Waltham, MA, USA), at a working volume of $20 \mathrm{~mL}, 25 \mathrm{~mL}, 50 \mathrm{~mL}$ or $100-200 \mathrm{~mL}$ in polycarbonate shake flasks of volume $125 \mathrm{~mL}, 250 \mathrm{~mL}$, $500 \mathrm{~mL}$ or $1 \mathrm{~L}$ (TriForest Enterprises, Irvine, CA, USA), respectively.

HEK293 suspension cells are originated from HEK293SF (clone 293SF-3F6) cells, which derive from a GMP-grade master cell bank [25]. The cells were cultured in HEK GM medium (Xell AG, Bielefeld, Germany), supplemented with 4 mM GlutaMAX. Routine passaging and incubation in shakers was the same as for suspension Vero cells.

Adherent Vero cells (ATCC CCL-81.5) were routinely passaged by washing with PBS without calcium and magnesium (WISENT Inc., Saint-Jean-Baptiste, QC, Canada), detaching with TrypLE ${ }^{\mathrm{TM}}$ Express Enzyme (Gibco, Gaithersburg, MD, USA) and adding VP Serum-Free Medium (VP-SFM) (Gibco, Gaithersburg, MD, USA) with 4 mM GlutaMAX and $1 \%$ Penicillin-Streptomycin solution (WISENT Inc., Saint-Jean-Baptiste, QC, Canada) to collect. Once collected, cells are pelleted at $300 \times g$ for $5 \mathrm{~min}$ and resuspended in VP-SFM to remove TrypLE. Cells are plated onto T-175 flasks or $150 \mathrm{~mm}$ plates, at $5-10 \times 10^{6}$ cells and are passaged every 2-3 days.

Adherent HEK293 (HEK293A, ATCC CRL-1573 [26]) cells were routinely passaged in the same way as adherent Vero cells, but using Dulbecco's Modified Eagle's Medium (DMEM) (Thermo Fisher Scientific, Waltham, MA, USA) with 10\% Fetal Bovine Serum (FBS) (Gibco, Gaithersburg, MD, USA) and 1\% Penicillin-Streptomycin solution instead of VP-SFM.

\subsection{Virus Adaptation}

The engineering and rescue of the Newcastle Disease Virus constructs NDV-GFP and NDV-FLS were described in another publication [27]. Briefly, the gene of interest (encoding green fluorescent protein or human codon-optimized full-length spike from SARS-CoV-2, respectively) was inserted between the $\mathrm{P}$ and $\mathrm{M}$ genes of the NDV (LaSota strain) genome. These viruses were initially produced in allantoic fluid and passaged for adaptation to Vero and HEK293 cells. Passages consisted of infecting cells, harvesting the virus produced and using it to reinfect cells for the next passage.

In Vero cells, for passages 1 and 2, adherent Vero cell cultures in T-25 flasks with VPSFM media and 4 mM GlutaMAX were infected at confluency of 80-90\% and an MOI of 0.5 with TPCK-treated trypsin (MilliporeSigma, Oakville, ON, Canada) to a final concentration of $1 \mu \mathrm{g} / \mathrm{mL}$. The supernatant was collected at $24 \mathrm{hpi}$. From passage 3 onwards, suspension Vero cells were seeded at $1 \times 10^{6}$ cells $/ \mathrm{mL}$ in $25 \mathrm{~mL}$ MDXK media with $4 \mathrm{mM}$ GlutaMAX in $250 \mathrm{~mL}$ shake flasks. The cells were immediately infected at an MOI of 0.01 with $1 \mu \mathrm{g} / \mathrm{mL}$ trypsin. At $36 \mathrm{hpi}$, the culture was centrifuged at $800 \times g$ for $5 \mathrm{~min}$ to collect the supernatant, which was stored at $-80{ }^{\circ} \mathrm{C}$.

In HEK293 cells, for all passages, suspension cells were seeded at $1 \times 10^{6}$ cells $/ \mathrm{mL}$ in $25 \mathrm{~mL}$ Xell HEK GM media with $4 \mathrm{mM}$ GlutaMAX in $250 \mathrm{~mL}$ shake flasks. The cells were immediately infected at an MOI of 0.01 with $1 \mu \mathrm{g} / \mathrm{mL}$ trypsin. At $36 \mathrm{hpi}$, the culture was centrifuged at $800 \times g$ for $5 \mathrm{~min}$ to collect the supernatant, which was stored at $-80^{\circ} \mathrm{C}$. 


\subsection{Median Tissue Culture Infectious Dose $\left(T C I D_{50}\right)$}

For routine quantification, adherent Vero cells were seeded on 96-well plates with 15,000 cells in $100 \mu \mathrm{L}$ of media (VP-SFM) per well. For media and cell line comparison during TCID $_{50}$ development, adherent HEK293 cells were used with DMEM. When using DMEM, BSA $2.5 \mu \mathrm{g} / \mathrm{mL}$ was added instead of FBS, to avoid trypsin activity inhibition. The following day, the media was aspirated and replaced by $100 \mu \mathrm{L}$ of media containing $1 \mu \mathrm{g} / \mathrm{mL}$ trypsin and a serial dilution of the virus (1:5 or 1:10). After 4 and 7 days of incubation at $37^{\circ} \mathrm{C}$ with $5 \% \mathrm{CO}_{2}$, wells were analyzed on a standard light microscope for cytopathic effect (CPE), consisting of rounded cells, a disrupted monolayer and/or clumps. The number of CPE-positive wells in each column was used to quantify the experiment by the Spearman and Kärber algorithm [28-30].

The assay with 1:5 dilutions (Coefficient of Variation: 34.57\%) was chosen for all the TCID 50 development and for samples which were below the range of detection of the 1:10 dilutions $\left(<3.16 \times 10^{2} \mathrm{TCID}_{50} / \mathrm{mL}\right)$. The assay with 1:10 dilutions (Coefficient of Variation: $34.69 \%$ ) was chosen for all samples from shake flask experiments and bioreactors.

For comparison of CPE readings and Alamar blue readings, CPE was read first on the microscope before addition of the dye. The cell viability reagent Alamar blue (Invitrogen, Waltham, MA, USA) was diluted 1:10 in PBS without calcium and magnesium, and $100 \mu \mathrm{L}$ of the dilution was added to each well, as described previously [31]. Plates were incubated at $37{ }^{\circ} \mathrm{C}$ with $5 \% \mathrm{CO}_{2}$ and the absorbance was analyzed after $4 \mathrm{~h}$. The absorbances at $570 \mathrm{~nm}$ and $600 \mathrm{~nm}$ were measured, and the absorbance at $600 \mathrm{~nm}$ was subtracted from the absorbance at $570 \mathrm{~nm}\left(\mathrm{ABS}_{570 \mathrm{~nm}}-\mathrm{ABS}_{600 \mathrm{~nm}}\right)$ to obtain the normalized value. Cut-off values were determined in a way that none of the wells in the (non-infected) negative control would be considered infected.

For comparison with fluorescence readings, a triplicate of an NDV-GFP sample was used for $\mathrm{TCID}_{50}$ and plates were read both by $\mathrm{CPE}$, using a standard light microscope, and by fluorescence, using a plate reader with the excitation at $485 / 20 \mathrm{~nm}$ and emission at $528 / 20 \mathrm{~nm}$.

After classifying the wells as positive through the cell viability (Alamar blue) or the fluorescence, the viral titer was determined by the Spearman and Kärber algorithm [28-30], in the same way as when reading CPE.

For fluorescent microscope imaging, the TCID 50 plates infected with NDV-GFP samples were observed on day 7 on Olympus IX-83 microscope using a $10 \times$ objective lens. Images were processed on ImageJ to merge bright-field images with green fluorescence channel images.

One-way ANOVA with the Tukey method was performed to determine statistical significance when comparing titration between different cell lines and different reading methods.

\subsection{Polymerase Chain Reaction (PCR)}

The Q5 High Fidelity Polymerase (New England Biolabs, Ipswich, MA, USA) was used with primers targeting the L gene (polymerase) of NDV: NDV-L F [5'-ATATGTTCTGACTCCTGCCC-3'] and NDV-L R [5'-TCTAGTCGCTTGATCTCTGC-3']. PCR was performed according to the manufacturer's instructions, with the following thermocycler program: initial denaturation $\left(1 \mathrm{~min}\right.$ at $\left.98^{\circ} \mathrm{C}\right)$, followed by 30 cycles of the steps: $10 \mathrm{~s}$ at $98^{\circ} \mathrm{C}, 30 \mathrm{~s}$ at the annealing temperature, $30 \mathrm{~s}$ at $72{ }^{\circ} \mathrm{C}$. Next, the final elongation step happens for 2 min at $72{ }^{\circ} \mathrm{C}$. The same NDV-GFP and NDV-FLS cDNA samples were used for PCR with different annealing temperatures: $56^{\circ} \mathrm{C}, 57.6^{\circ} \mathrm{C}, 59.2^{\circ} \mathrm{C}$ and $60{ }^{\circ} \mathrm{C}$. The amplified bands were visualized in a $2.5 \%$ agarose gel with SYBR Safe DNA gel stain (Thermofisher, Waltham, MA, USA).

\subsection{Digital Droplet Polymerase Chain Reaction (ddPCR)}

For routine quantification, RNA extraction was done for $20 \mu \mathrm{L}$ of supernatant samples diluted with $180 \mu \mathrm{L}$ PBS (without calcium and magnesium) using the High Pure Viral Nucleic Acid kit (Roche, Basel, Switzerland). During assay development, different dilutions 
of the sample were also tested: $1 \times$ (no dilution-200 $\mu \mathrm{L}$ sample), $4 \times(50 \mu \mathrm{L}$ sample with $150 \mu \mathrm{L}$ PBS $)$ and $10 \times(20 \mu \mathrm{L}$ sample with $180 \mu \mathrm{L}$ PBS $)$. Next, $2 \mu \mathrm{L}$ of the extracted RNA was used with the iScript Select cDNA synthesis kit (Bio-Rad Laboratories, Hercules, CA, USA) to generate cDNA using random RT-PCR primers. Then, the cDNA was diluted (between $1: 10$ to $1: 10,000)$ to target the linear range of ddPCR. $5 \mu \mathrm{L}$ of the template dilution was used with the QX200 ddPCR kit (Bio-Rad Laboratories, Hercules, CA, USA), using the EvaGreen master mix and the same primers listed for PCR. The manufacturer's instructions were followed to prepare the reaction and generate droplets. As for the thermocycler program: after initial denaturation $\left(5 \mathrm{~min}\right.$ at $\left.95^{\circ} \mathrm{C}\right), 34$ cycles of the following steps were repeated: $30 \mathrm{~s}$ at $95^{\circ} \mathrm{C}, 1 \mathrm{~min}$ at $59^{\circ} \mathrm{C}, 30 \mathrm{~s}$ at $72{ }^{\circ} \mathrm{C}$. Then, the final elongation step happened for $5 \mathrm{~min}$ at $72{ }^{\circ} \mathrm{C}$.

Droplets are analyzed individually in the droplet reader and the copies $/ \mu \mathrm{L}$ of each sample is given. This output is corrected for the dilution and volumes used to determine the viral genomes/mL of the original sample with the following calculation:

$$
\text { Viral genomes } / \mathrm{mL}=\mathrm{I} \times \mathrm{J} \times \mathrm{K} \times(\mathrm{L} / \mathrm{M}) \times(\mathrm{O} / \mathrm{N}) / \mathrm{P} \times \mathrm{Q} \times 1000,
$$

in which: $\mathrm{I}=$ Copies $/ \mu \mathrm{L}$ (ddPCR output); $\mathrm{J}=$ volume of the ddPCR reaction; $\mathrm{K}=$ dilution of the cDNA template; $\mathrm{L}=$ volume of $\mathrm{RT}-\mathrm{PCR}$ reaction; $\mathrm{M}=$ volume of the $\mathrm{CDNA}$ dilution added in the ddPCR reaction; $\mathrm{N}=$ volume of $\mathrm{RNA}$ added in the RT-PCR reaction; $\mathrm{O}=$ elution volume for RNA extraction; $\mathrm{P}=$ initial sample volume used for the RNA extraction; $\mathrm{Q}=$ dilution of the sample in RNA extraction.

\subsection{Design of Experiment (DoE) for Infection Parameters}

A two-level full factorial design was done with triplicates of each condition to screen 3 parameters at infection: trypsin concentration (from 1 to $5 \mu \mathrm{g} / \mathrm{mL}$ ), trypsin addition (no repeated addition or addition at $24 \mathrm{~h}$ ) and temperature (from 34 to $37^{\circ} \mathrm{C}$ ). To start the experiment, cultures of suspension Vero cells were centrifuged at $800 \times g$ for 5 min and seeded at $1 \times 10^{6}$ cells $/ \mathrm{mL}$ in $30 \mathrm{~mL}$ MDXK media with $4 \mathrm{mM}$ GlutaMAX in $250 \mathrm{~mL}$ shake flasks. The flasks were immediately infected with NDV-FLS at an MOI of 0.01 using the chosen DoE parameters. For trypsin addition at $24 \mathrm{~h}$, trypsin was added to a final concentration of 1 or $5 \mu \mathrm{g} / \mathrm{mL}$, according to the initial trypsin concentration assigned to each flask. Viral samples were taken at $30 \mathrm{hpi}$ by centrifuging at $800 \times g$ for 5 min and aliquoting the supernatant (storage at $-80^{\circ} \mathrm{C}$ ). Samples were quantified by TCID 50 and analyzed with the Design Expert 13 software (Stat-Ease Inc., Minneapolis, MN, USA) using base 10 log-transformed values. Statistical significance was determined through ANOVA, followed by several residual analyses and diagnostics to confirm the quality of the model.

\subsection{Multiplicity of Infection (MOI) Optimization}

4 different multiplicities of infection (MOI) were evaluated: 0.1, 0.01, 0.001 and 0.0001 IVP/cell. Cultures of suspension Vero cells were centrifuged at $800 \times g$ for 5 min and seeded at $1 \times 10^{6}$ cells $/ \mathrm{mL}$ in $25 \mathrm{~mL}$ MDXK media with $4 \mathrm{mM}$ GlutaMAX in $250 \mathrm{~mL}$ shake flasks. Immediately, cells were infected with NDV-FLS at the corresponding MOIs with $1 \mu \mathrm{g} / \mathrm{mL}$ trypsin, in triplicates. Shake flasks were incubated at $37^{\circ} \mathrm{C}, 135 \mathrm{rpm}$ and $5 \% \mathrm{CO}_{2}$ and samples were taken every $12 \mathrm{~h}$ after infection. For sampling, $0.8 \mathrm{~mL}$ culture of each flask was taken and spun down at $800 \times g$ for $5 \mathrm{~min}$ to aliquot the supernatant (storage at $-80^{\circ} \mathrm{C}$ ). Viral samples were quantified by $\mathrm{TCID}_{50}$ and triplicates were averaged to plot the viral production kinetics of each MOI. The peak values of viral production for each MOI were compared in a one-way ANOVA with the Tukey method to investigate statistical significance.

\subsection{Bioreactors}

For $1 \mathrm{~L}$ bioreactors, a culture of 650 to $850 \mathrm{~mL}$ was seeded at $2.5 \times 10^{5}$ cells $/ \mathrm{mL}$ in MDXK with $4 \mathrm{mM}$ glutamine. The bioreactors (Applikon Biotechnology, Delft, The Netherlands) were assembled with a marine impeller for stirring and sensors for dissolved 
oxygen (DO) concentration, temperature and $\mathrm{pH}$. The following parameters were controlled in the system: $\mathrm{pH}$ at 7.2 , temperature at $37^{\circ} \mathrm{C}, \mathrm{DO}$ at $40-50 \%$ and stirring at $100 \mathrm{rpm}$. $\mathrm{DO}$ was maintained by a constant airflow in the headspace of $10 \mathrm{~mL} / \mathrm{min}$, along with pure oxygen sparging when necessary. The $\mathrm{pH}$ was regulated by addition of $\mathrm{CO}_{2}$ in the headspace or injection of $\mathrm{NaHCO}_{3}(90 \mathrm{~g} / \mathrm{L})$ (Sigma, USA).

Samples were taken every $24 \mathrm{~h}$ to monitor cell growth using the Vi-CELL XR Cell Viability Analyzer (Beckman Coulter Life Sciences, Brea, CA, USA). Glutamine was injected at $1 \mathrm{mM}$ daily. For virus production, cells were infected at an MOI of $0.01 \mathrm{IVP} /$ cell with $1 \mu \mathrm{g} / \mathrm{mL}$ trypsin on day 4 or 5 of culture, when cell density was approximately $8 \times 10^{5}$ cells $/ \mathrm{mL}$. After infection, samples were taken every $12 \mathrm{~h}$ and the supernatant was obtained by centrifuging at $800 \times g$ for $5 \mathrm{~min}$ (storage at $-80^{\circ} \mathrm{C}$ ).

\section{Results}

\subsection{Development and Optimization of Analytical Assays}

\subsubsection{Cell Line Assessment for $\mathrm{TCID}_{50}$ Set-Up}

Adherent Vero and HEK293 cells were compared in order to choose the most adequate cell line for the development of a $\mathrm{TCID}_{50}$ assay, to quantify infectious viral particles in culture supernatants. When using NDV-GFP and NDV-FLS viral samples to infect both cell lines in $\mathrm{TCID}_{50}$ assays, evident differences were observed upon visual inspection of cytopathic effect, as well as in the measured titers and fluorescence detection (Figure 1). These TCID 50 plates were incubated for 7 days after infection, and analyzed on days 4 and 7 .

A

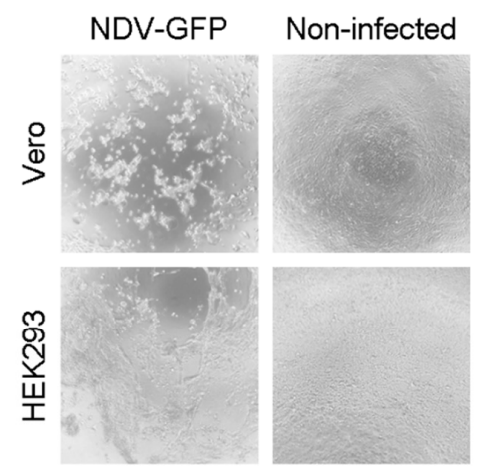

C

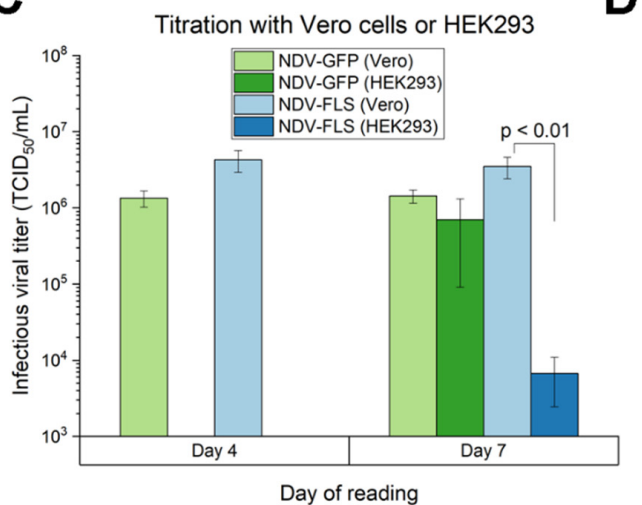

B

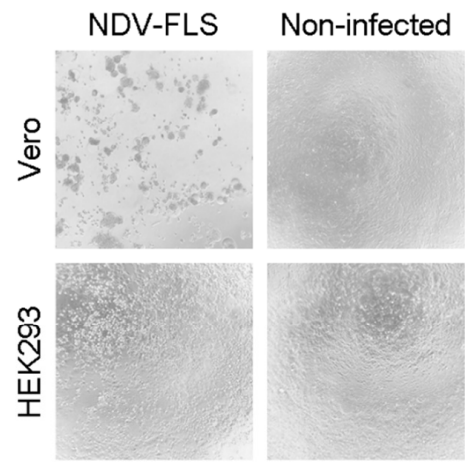

D

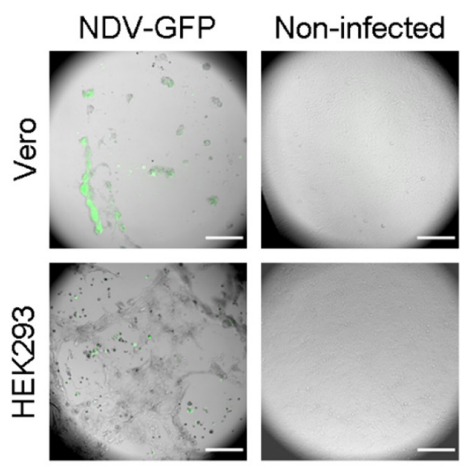

Figure 1. Comparison between Vero cells in VP-SFM or HEK293 in DMEM for quantification by TCID 50 of NDV-GFP and NDV-FLS viruses. (A,B) Cytopathic effect seen in Vero and HEK293 adherent cells after 7 days of incubation with the two different viruses: NDV-GFP (A) and NDV-FLS (B). The comparisons show an infected well in TCID $_{50}$ and a negative control well, with no virus. (C) Infectious titers obtained by quantifying the same NDV-GFP and NDV-FLS viral samples using Vero or HEK293 cells for TCID 50 . Error bars correspond to the average of triplicate plates \pm standard deviation. Statistically significant differences are labeled with the corresponding $p$-value. (D) Fluorescence detection in TCID 50 wells infected with NDV-GFP in Vero or HEK293 cells, compared with the respective non-infected negative controls. The images show a merge of the green fluorescence channel (GFP) with the bright-field image (cells). Scale bar corresponds to $250 \mu \mathrm{m}$. 
When comparing the cytopathic effect generated on each cell line by the same virus inoculum, NDV-GFP induced a strong effect in Vero and HEK293, forming large clumps of non-viable cells and completely disrupting the cell monolayer after 7 days of incubation (Figure 1A). However, with NDV-FLS, the cytopathic effect was more evident in Vero cells than in HEK293 (Figure 1B). Like NDV-GFP, it caused the formation of aggregates and disrupted the Vero cell monolayer, but in HEK293 the cytopathic effect was limited to individual rounded cells, with very rare clumping. Even in Vero cells, NDV-FLS showed a slightly smaller cytopathic effect when compared to NDV-GFP (Figure S1), forming smaller aggregates that were still clearly distinguishable from the non-infected cells. When comparing different media for adherent Vero, cytopathic effect for both viruses was more noticeable when using VP-SFM (Figure S1). DF-1 cells were also tested in the TCID 50 assay, but cytopathic effect was not discernible compared to non-infected cells, even after 7 days of incubation.

For both viruses, 4 days of incubation in HEK293 was not enough to allow for quantification, as the cytopathic effect was still difficult to distinguish from non-infected cells. This was only possible on day 7 of incubation (Figure 1C). With Vero cells, on the other hand, cytopathic effect was already distinguishable on day 4 , allowing for an earlier quantification. When comparing the quantification for the same viral sample in the different cell lines on day 7, NDV-GFP had no significant differences, but the titer for NDV-FLS obtained with Vero cells was significantly higher $(p<0.01)$ than with HEK293. This was in line with the more subtle cytopathic effect observed with NDV-FLS in HEK293, which resulted in a more difficult reading and apparent lower titers. Since both constructs came from egg-derived aliquots with similar yielding passages, the titers observed when quantifying with Vero cells were more adequate, with both constructs resulting in similar titers.

Lastly, the TCID 50 plates infected with NDV-GFP were imaged under an inverted confocal fluorescence microscope. In Vero cells, the aggregates seen in the cytopathic effect were paired with strong fluorescence (Figure 1D). In HEK293, however, there was less fluorescence, even when abundant cytopathic effect was present. Although NDV-GFP showed signs of infection in both cell lines, GFP production was higher in Vero cells.

When analyzing all three aspects (cytopathic effect, titers and fluorescence), Vero cells seemed to be more suitable for NDV titration than HEK293 cells, with distinguishable cytopathic effect, higher titer and fluorescence, aside from allowing quantification within a shorter period of time. Thus, adherent Vero cells were chosen as the most appropriate cell line for the $\mathrm{TCID}_{50}$ assay and were used in all subsequent quantifications.

3.1.2. Quantification of NDV Infectious Particles through Fluorescence Measurements and Viability-Based Assays

The next step in $\mathrm{TCID}_{50}$ development was to use a plate reader to test alternative methods of reading, which do not require subjectively analyzing cytopathic effect on a microscope. For NDV-GFP, the green fluorescence was read on a plate reader to determine the infected wells and calculate the infectious titer (Figure 2A). When quantifying the same sample by cytopathic effect or by fluorescence, there was no statistically significant difference between the two methods, both on day 4 and day 7 ( $p=0.5653$ and $p=0.8301$, respectively). This showed that fluorescence can also be used for quantification and that the virus infected the cells, simultaneously expressing detectable GFP. Most wells with cytopathic effect also showed fluorescence on days 4 and 7 (95.48\% and $98.92 \%$, respectively). 
A

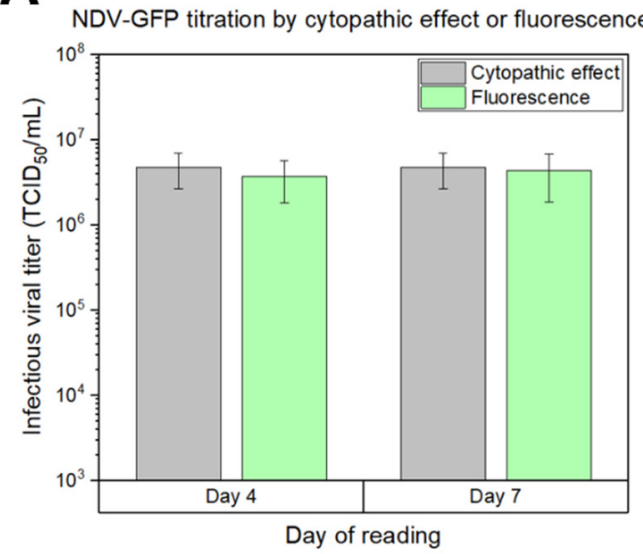

B
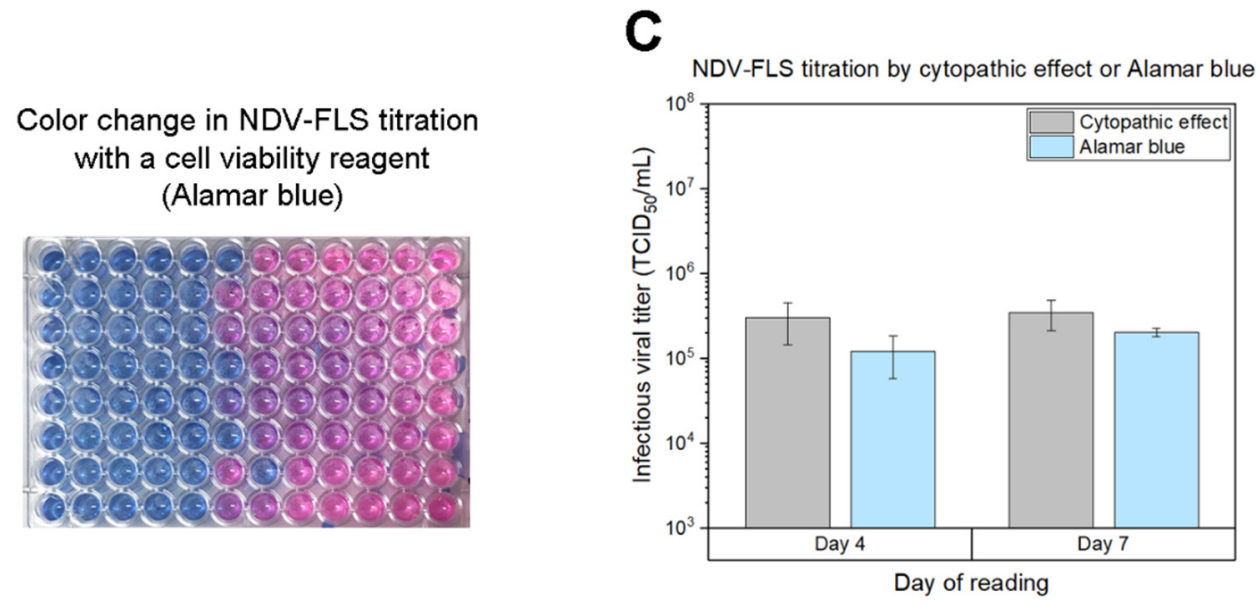

Figure 2. Different titration assays for NDV infectious particle determination. (A) Titration of the same sample of NDV-GFP in triplicate quantified by $\mathrm{CPE}$ and by fluorescence. Error bars correspond to the average of triplicate plates \pm standard deviation. (B) TCID 50 plate (on day 7) after $4 \mathrm{~h}$ of incubation with a cell viability reagent (Alamar blue). Blue wells corresponded to infected/dead cells (low viability) while pink wells corresponded to non-infected/healthy cells (high viability). (C) Titration of the same sample of NDV-FLS in triplicates quantified by CPE and by the cell viability reagent Alamar blue. Error bars correspond to the average of triplicate plates \pm standard deviation.

Since fluorescence can only be used to quantify NDV constructs bearing the GFP coding sequence, a reading method based on cell viability was also evaluated. For TCID 50 calculations, the plates were incubated with a cell viability reagent (Alamar blue), resulting in infected wells that remained blue while the non-infected ones, containing healthy cells, became red/pink (Figure 2B). The infectious titer of the same NDV-FLS sample was quantified by cytopathic effect observation on the microscope and by cell viability staining, resulting in similar titers and no statistically significant differences between both methods on day 4 and day 7 ( $p=0.1395$ and $p=0.1478$, respectively) (Figure 2C).

\subsection{3. ddPCR-Based Quantification of NDV}

A quantification assay based on digital droplet PCR (ddPCR) was developed to measure total viral particles. First, different annealing temperatures were tested by PCR to confirm specificity, using NDV-GFP and NDV-FLS samples (Figure 3A). For all temperatures tested with both viruses, the expected amplification product was observed, without presence of non-specific bands. 
A
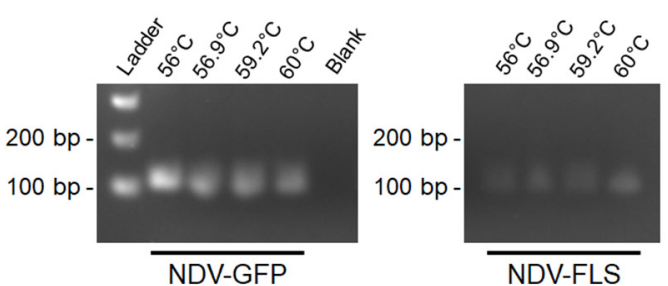

NDV-GFP
B

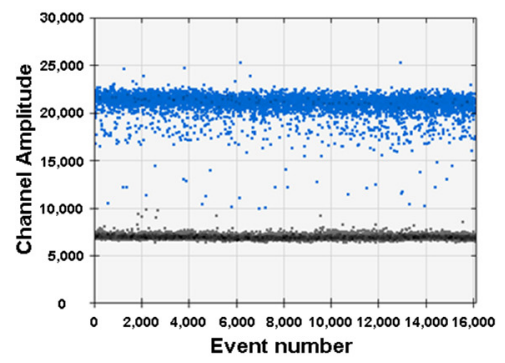

C

$\mathrm{TCID}_{50}$ and ddPCR quantification for NDV-GFP and NDV-FLS

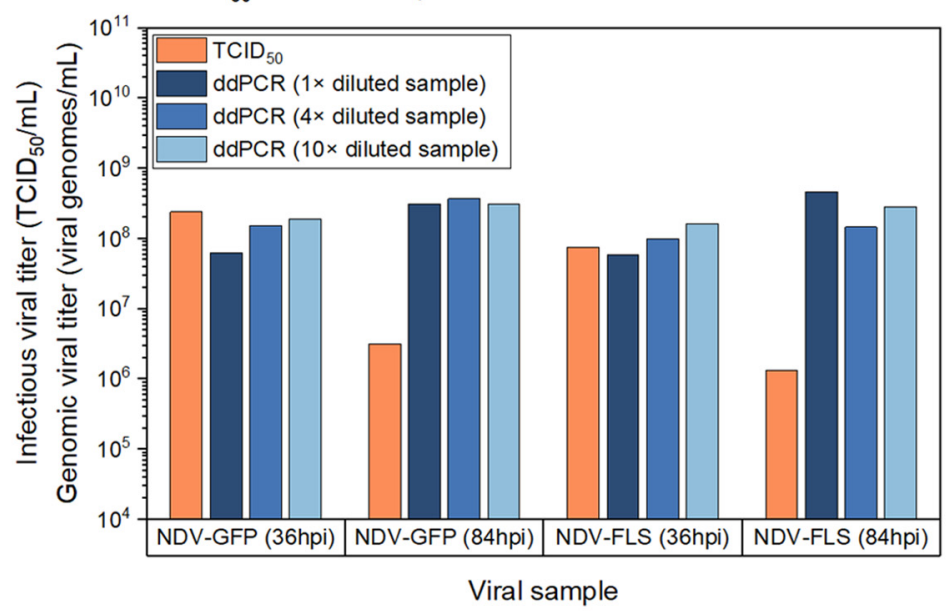

Figure 3. Development of a digital droplet PCR (ddPCR) assay for quantification of NDV. (A) Agarose DNA gel to verify PCR reactions at different annealing temperatures with primers designed for ddPCR, targeting the NDV-L (polymerase) gene on an NDV-GFP and an NDV-FLS sample. The expected band is $117 \mathrm{bp}$. (B) Plot showing positive (blue) and negative (dark grey) events in ddPCR. (C) Comparison between each sample's infectious titer $\left(\mathrm{TCID}_{50} / \mathrm{mL}\right.$ ) with the genomic titer (viral genomes $/ \mathrm{mL}$ ) quantified by ddPCR. For ddPCR, different dilutions of the viral sample in RNA extraction were used: a non-diluted sample $(1 \times)$, a 4 times diluted sample $(4 \times)$ and a 10 times diluted sample $(10 \times)$. Sample dilutions were taken into account in the calculation of final titers. Samples of NDV-FLS and NDV-GFP at a peak production time point (36 h post infection) and late time point (84 h post infection) were used.

Next, the chosen primers were used for ddPCR, with the selected annealing temperature of $59{ }^{\circ} \mathrm{C}$. Individually partitioned events were clearly defined as positive or negative (Figure 3B), indicating proper functioning of the assay. When performing ddPCR on viral samples from peak production time points (36 hpi), the genomic titer was similar or higher than the infectious titer quantified by $\operatorname{TCID}_{50}$ (Figure 3C). For later time points ( $84 \mathrm{hpi}$ ), the genomic titer was notably higher than the infectious titer, as the infectious titer decreased, and the genomic titer remained constant. Out of the three sample dilutions for the viral supernatant tested in the RNA extraction step, the $10 \times$ dilution was selected for the genomic quantification of NDV in subsequent experiments.

\subsection{Evaluation of NDV Infection and Production Parameters}

The two viral constructs, which were initially produced in eggs and contained in allantoic fluid, were serially passaged in Vero and HEK293 cell lines for adaptation (Figure 4A,B). 


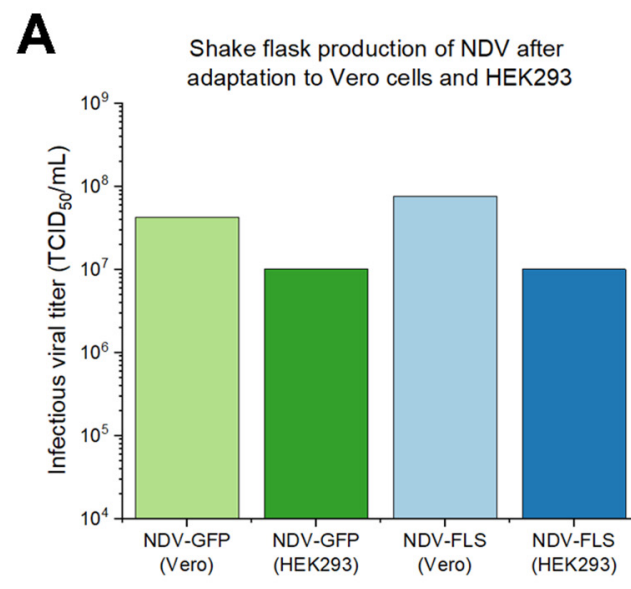

B
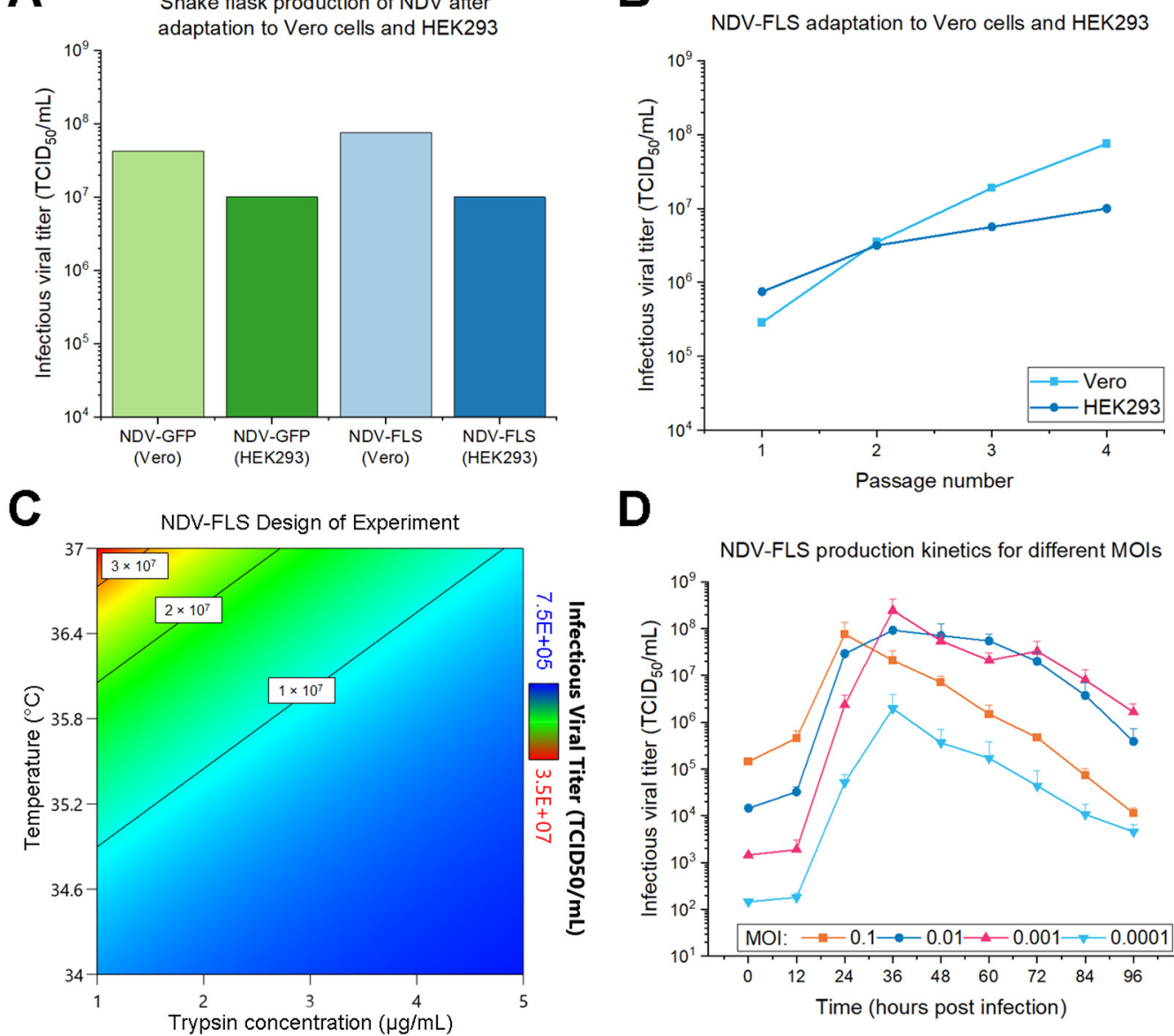

D

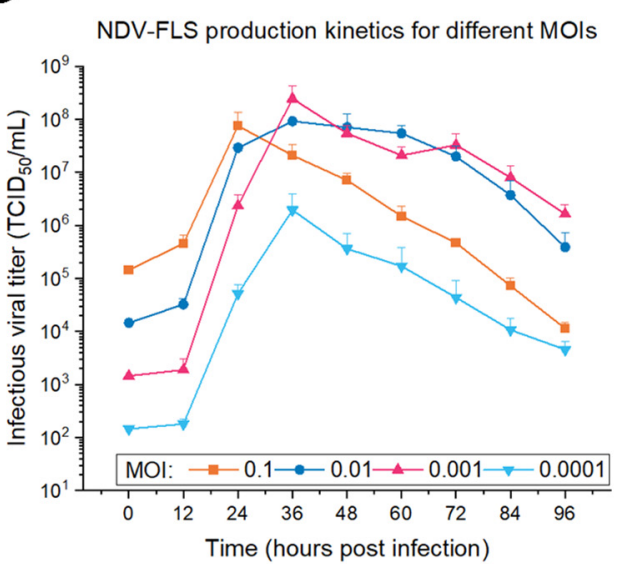

Figure 4. Optimization of infection parameters in small scale shake flask productions. (A) Infectious viral titers achieved in the fourth round of infection (passage 4) of each NDV construct in the two cell lines evaluated. (B) Serial passaging of NDV-FLS in Vero and HEK293 cells for viral adaptation. The first two passages in Vero were conducted in adherent cells with MOI $=0.5$. Passages 3 and 4 were conducted in suspension cells with MOI $=0.01$. For HEK293, suspension cells infected at MOI $=0.01$ were used in all the passages. (C) Design of experiment (DoE) modeling for production of NDV-FLS, showing the highest viral titer produced at $37^{\circ} \mathrm{C}$ with $1 \mu \mathrm{g} / \mathrm{mL}$ trypsin added to the culture media. (D) Viral production kinetics for NDV-FLS using the MOIs 0.1 to 0.0001 , with the highest titer achieved of around $1.00 \times 10^{8} \mathrm{TCID}_{50} / \mathrm{mL}$. Time is shown as hours post infection (hpi). Error bars correspond to the average titer calculated from shake flask triplicates + standard deviation.

For both NDV-GFP and NDV-FLS, higher infectious titers were achieved in Vero than in HEK293 cells after adaptation. Viral production in Vero cells at passage 4 was $4.22 \times 10^{7} \mathrm{TCID}_{50} / \mathrm{mL}$ for NDV-GFP and $7.50 \times 10^{7} \mathrm{TCID}_{50} / \mathrm{mL}$ for NDV-FLS, while production in HEK293 reached a maximum of $1.00 \times 10^{7} \mathrm{TCID}_{50} / \mathrm{mL}$ for both viruses (Figure 4A). As shown for NDV-FLS (Figure 4B), both cell lines started with productions lower than $3 \times 10^{6} \mathrm{TCID}_{50} / \mathrm{mL}$ at passage 1 and showed increased viral titers as passages progressed. This increase throughout adaptation was higher in Vero cells (over 250-fold) than in HEK293 (less than 20-fold). After passage 4, subsequent passaging for NDV-FLS or NDV-GFP did not increase the titer levels. Thus, suspension Vero cells were selected for NDV production and further optimizations.

Next, a two-level full factorial design of experiment was done to determine parameters for infection with NDV-FLS (Figure 4 C). Temperature $(p<0.0001)$ and trypsin concentration at infection $(p=0.0004)$ impacted infectious titers significantly, with the best condition being $1 \mu \mathrm{g} / \mathrm{mL}$ of trypsin and incubation at $37^{\circ} \mathrm{C}$. The third parameter, however, which was trypsin addition at $24 \mathrm{~h}$ post infection vs. no repeated addition, showed no statistically significant difference $(p=0.3271)$. As such, the best conditions were used for the next experiments, with no repeated trypsin addition. 
Additionally, different MOIs were tested for NDV-FLS, ranging from 0.1 to 0.0001 (Figure 4D). The lowest MOI (0.0001) had the lowest peak of viral production $\left(1.96 \times 10^{6} \mathrm{TCID}_{50} / \mathrm{mL}\right)$, while the other 3 MOIs $(0.1-0.001)$ all reached similar peaks around $1.00 \times 10^{8} \mathrm{TCID}_{50} / \mathrm{mL}$, with no significant differences $(p=0.178)$. As expected, the highest MOI showed the earliest peak, at $24 \mathrm{hpi}$, while the next two MOIs (0.01 and 0.001) peaked at 36 hpi. Despite having an earlier peak, the infectious titer with MOI 0.1 dropped considerably as time progressed to $96 \mathrm{hpi}$, declining to similar titers as those reached at the lowest MOI. Although the MOIs 0.01 and 0.001 also showed a loss in infectious titer after the peak, the losses were the smallest when compared to other MOIs. Therefore, the MOI 0.01 was chosen for the following viral productions, with a high peak of production and adequate stability. Upon applying the selected conditions to the NDV-GFP construct, the titer of $1.07 \times 10^{8} \mathrm{TCID}_{50} / \mathrm{mL}$ was obtained in shake flasks.

\subsection{Production in Bioreactors}

After parameter optimization in shake flasks, the next aim was to produce the viruses in suspension Vero cells using stirred tank bioreactors. A $1 \mathrm{~L}$ batch bioreactor was performed for production of NDV-GFP (Figure 5A) and NDV-FLS (Figure 5B). Infectious titers quantified for both viruses showed the ability of the system to reach peaks in the orders of $10^{8}$ and $10^{7} \mathrm{TCID}_{50} / \mathrm{mL}$, respectively.

A

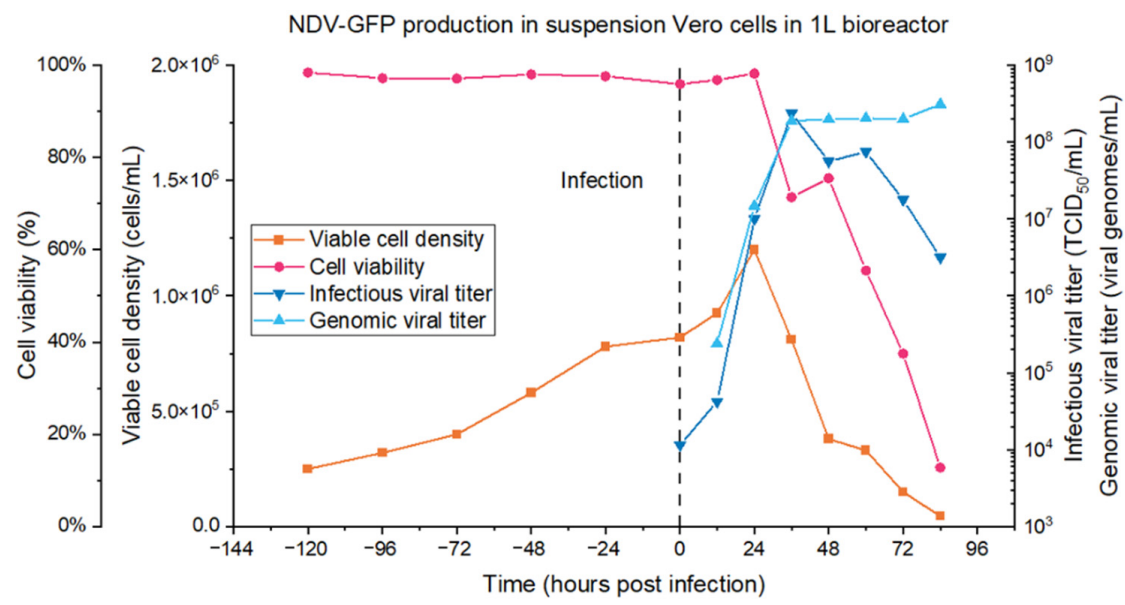

B

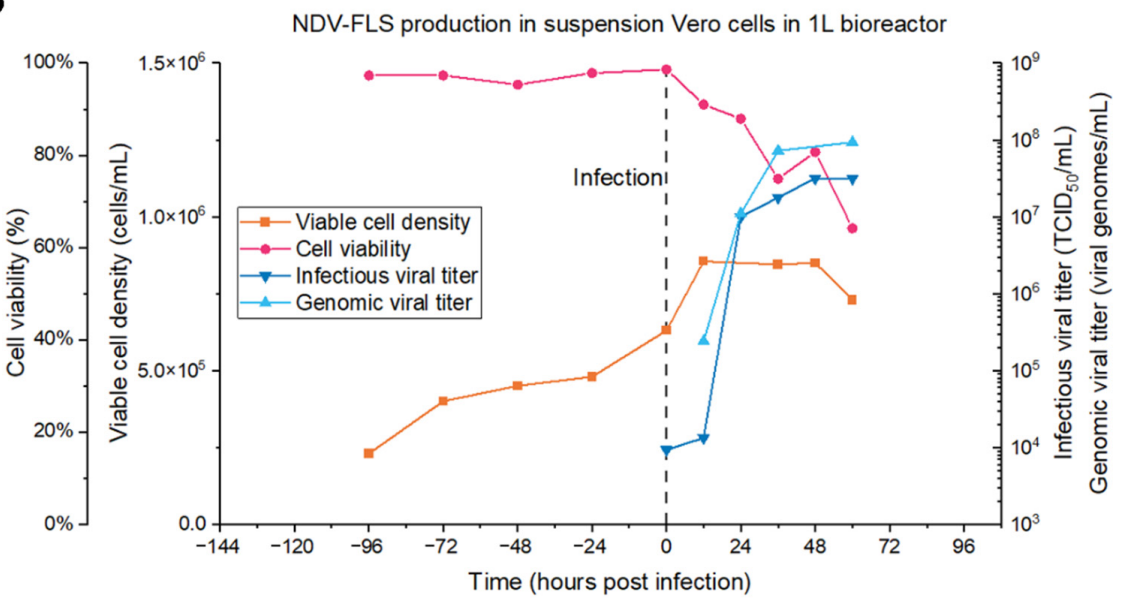

Figure 5. Batch bioreactor production of NDV-GFP (A) and NDV-FLS (B) at the $1 \mathrm{~L}$ scale. Offline measurements were taken by regular sampling. Infectious viral titers were quantified by $\mathrm{TCID}_{50}$ and total/genomic viral titers were quantified by ddPCR. The time of infection is indicated by a black dashed line in the figure. 
For NDV-GFP (Figure 5A), the infectious titers peaked at $36 \mathrm{hpi}$, reaching $2.37 \times 10^{8} \mathrm{TCID}_{50} / \mathrm{mL}$, after which values decreased over time, dropping to $3.16 \times 10^{6} \mathrm{TCID}_{50} / \mathrm{mL}$ at $84 \mathrm{hpi}$. The total viral titer, on the other hand, remained constant after the peak production, at around $2.00 \times 10^{8} \mathrm{VGs} / \mathrm{mL}$. The virus also affected cell viability, as seen with the considerable drop to below $80 \%$ observed at $36 \mathrm{hpi}$, that reached below $20 \%$ by the end of the bioreactor run at $84 \mathrm{hpi}$.

For NDV-FLS (Figure 5B), the peak production was $3.16 \times 10^{7} \mathrm{TCID}_{50} / \mathrm{mL}$ at $48 \mathrm{hpi}$, which remained constant until $60 \mathrm{hpi}$. The genomic titer was higher than the infectious titer, plateauing at around $1 \times 10^{8} \mathrm{VGs} / \mathrm{mL}$ from the peak production onwards. A decrease in cell viability was observed post infection, dropping to lower than $65 \%$ at $60 \mathrm{hpi}$.

The online measurements for bioreactor productions of NDV showed that $\mathrm{pH}$, temperature and $\mathrm{DO}$ were maintained constant during the cell growth and virus production phases (Figure 6) through effective control strategies, including the addition of oxygen.

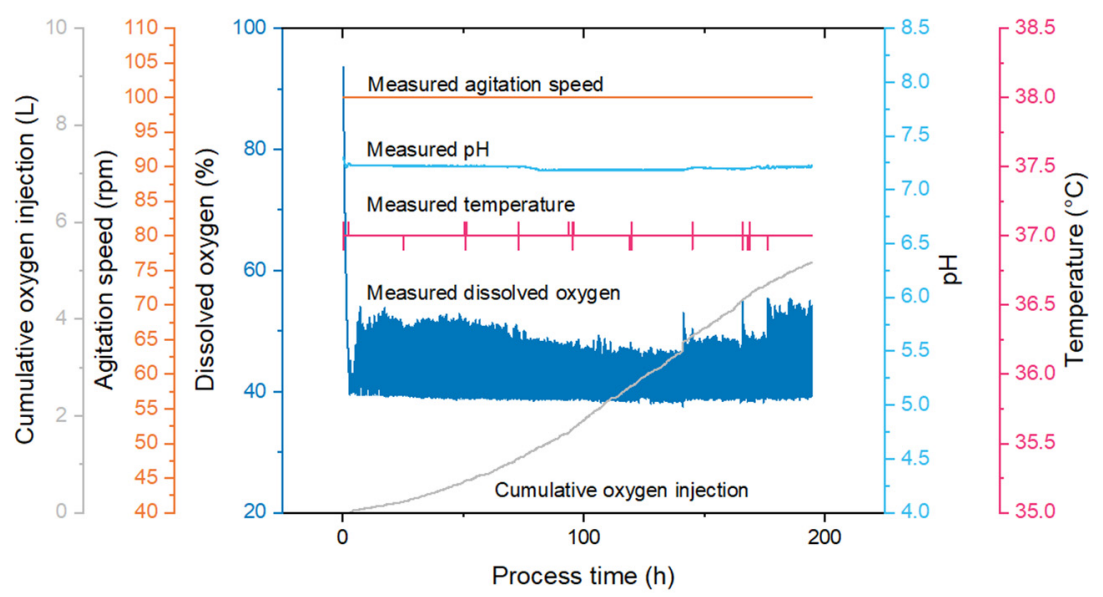

Figure 6. Online bioreactor measurements recorded throughout a batch bioreactor production of NDV-FLS at the $1 \mathrm{~L}$ scale.

\section{Discussion}

NDV is a promising viral vector for vaccine development that has been studied for its potential application against several human diseases, and it is still commonly produced in embryonated chicken eggs [2]. In this study, we set out to provide an alternative for NDV production by developing the foundation for a cell culture-based production process. Bioprocesses for vaccine manufacturing are composed of an upstream phase, a downstream phase, and the analytics used throughout the entire process to quantify the production and optimizations. Here, we developed analytical assays and evaluated upstream process parameters by testing cell lines for production, adapting the virus to suspension cell cultures and comparing several infection conditions. After this evaluation, we applied the selected parameters to produce NDV in $1 \mathrm{~L}$ scale bioreactors.

MDCK and Vero cells are well established systems for viral vaccine production, but a range of other continuous cell lines (CCLs) have also been studied for this purpose, including HEK293. While HEK293 shows promise as a cell line that has been adapted for suspension and grows to high densities in serum-free media [32], manufacturers tend to prefer processes using established cells for faster licensing [33]. Vero cells have a long history of proven safety, being the first CCL approved for viral vaccine production for human use. From a process perspective, these cells are commonly used with adherent cell culture technologies, such as microcarriers or fixed bed bioreactors, which are labor intensive and limited by surface area, resulting in a difficult scale up [20]. However, recent advances in adapting Vero cells to suspension have been successful [24], as these suspension Vero cells have been shown to work for virus production using stirred tank bioreactors in batch [34] and perfusion [24] modes. These cells have also been adapted to grow in the serum-free commercially available MDXK medium, after screening with several other 
media [34]. Recently, this cell line's genome has been sequenced through de novo assembly and annotated, facilitating future genome editing approaches [35]. Furthermore, Vero cells are interferon-deficient [35], making them susceptible to a wide range of viruses that have achieved high productivity when produced in Vero cells [20].

In this study, suspension Vero cells showed the additional ability of yielding higher viral titers for both NDV-GFP and NDV-FLS constructs, which was in line with the more evident $\mathrm{CPE}$ and intensity of fluorescence observed in adherent Vero cells when compared to HEK293. Serial passaging of NDV in Vero cells led to an increase in titer after four passages, similar to what has been shown for other strains of NDV [36], in which the number of passages required for such an increase varied for each strain. This increase is expected, as the viruses were originally collected in allantoic fluid, and viral adaptation to cell culture may select for viruses with more efficient replication in the new host cell. Further characterization of the viruses adapted to these cell lines could be important to evaluate if there were changes to safety, efficacy and abundance of recombinant protein on the viral surface when compared to the virus produced in eggs.

After defining suspension Vero as the cell line of choice for NDV production, a DoE revealed that the highest NDV-FLS titers were obtained when infecting at $37^{\circ} \mathrm{C}$ with $1 \mu \mathrm{g} / \mathrm{mL}$ trypsin, and that repeated trypsin addition had no significant effect. VSV titers are influenced by the temperature in the production phase, and each construct has an optimal temperature [34]. As the LaSota strain of NDV is not thermostable [37], similarly to VSV, a lower temperature could have resulted in higher viral titers. However, a production temperature of $37^{\circ} \mathrm{C}$ led to significantly higher titers than $34^{\circ} \mathrm{C}$, ruling out the use of low temperatures for these NDV constructs. This may be in line with the $37^{\circ} \mathrm{C}$ incubation step that is typically implemented when producing NDV in embryonated eggs $[18,38]$. As for trypsin, the concentrations tested were 1 and $5 \mu \mathrm{g} / \mathrm{mL}$, which are values reported in the literature for NDV experiments [37,39]. In our study, the highest NDV titers were achieved with the lowest trypsin concentration, which is similar to what has been observed for influenza virus [17]. Vero cells are known to produce trypsin inhibitors [40], and multiple additions of trypsin have been described as having a positive effect [41] or no effect [40] on the multi-cycle production of influenza in this cell line. For NDV, we found that repeated trypsin addition had no apparent effect on the viral titer produced, which prompted us to add trypsin only at the moment of infection.

A range of MOIs (0.1-0.0001) that encompasses the MOIs used for NDV in previous works $[37,39,42]$ was also evaluated. With the exception of the lowest one tested, all MOIs reached a similar peak of approximately $1 \times 10^{8} \mathrm{TCID}_{50} / \mathrm{mL}$. The viral production peak was $24 \mathrm{hpi}$ for the highest MOI (0.1), and shifted to a later time point (36 hpi) with lower MOIs. However, this higher MOI showed a greater and earlier loss of infectivity than the next two MOIs assayed (0.01 and 0.001). For the $0.01 \mathrm{MOI}$, the titer remained relatively constant until $60 \mathrm{hpi}$, and was still higher than the $0.1 \mathrm{MOI}$ by the end of the experiment at $96 \mathrm{hpi}$. Such stability is important for a robust process, as it is more likely to result in an adequate yield even if production kinetics shift due to variations in the process. The 0.01 MOI was chosen for the process, since an MOI 10 times lower still yielded similar results, and thus possible volume errors when adding the virus at $0.01 \mathrm{MOI}$ would still lead to a reliable production. Overall, from the first passage in Vero cells to the last shake flask optimization experiment, the produced NDV-FLS titers increased by almost 320-fold, from $2.87 \times 10^{5} \mathrm{TCID}_{50} / \mathrm{mL}$ to $9.17 \times 10^{7} \mathrm{TCID}_{50} / \mathrm{mL}$, indicating that the selection of culture and infection parameters was adequate.

Aside from the cell lines and infection parameters used, analytics are also an essential part of the production process that should not be overlooked. The virus being produced must be characterized and quantified throughout several steps of manufacturing to generate crucial data for process development and for regulatory approval [43]. As a replicative viral vector [2], NDV can be quantified regaring the replication-competent particles-also known as functional or infectious titer-and regarding the total particles, which may or may not be functional. The ratio between these two titers is indicative of quality and can 
be used to assess different time points or conditions of the process [44]. As such, when developing a process, it is important to establish reliable and scalable analytical methods to increase feasibility of implementing this process in large scale, consequently improving the chances of quickly achieving mass vaccination for a new pathogen of concern.

In this study, not only have we developed assays for each type of quantification, but we have also established methods of reading the TCID 50 assay amenable to automation. NDV-GFP was quantified by reading fluorescence on a plate reader, while other constructs, such as NDV-FLS, can also be quantified on a plate reader when paired with a reagent that detects viability. Alamar blue is a blue dye based on resazurin, which changes to a red color when reduced to resorufin in metabolically active cells, indicating cell health [45]. Both fluorescence and viability were shown to be comparable to CPE quantification, resulting in valid methods of reading $\mathrm{TCID}_{50}$. As these methods rely on plate readers, and not visual inspection, they are non-subjective and can be automated for use in industry or for standardization across collaborating institutions and facilities. Therefore, the availability of these tools makes the assay more feasible for high throughput processes and industrial application. Antibody-based assays, such as an immunofluorescence assay (IFA) [18,46], could also be of interest, as they can be targeted to quantify only viruses that contain the protein required for immunization, which could be important in vaccine manufacturing. This specificity, however, means having to adapt the assay with a different antibody for each new construct, which could slow down the development of new vaccines using the platform. Therefore, $\mathrm{TCID}_{50}$ and ddPCR assays were chosen, as they can be used for any NDV construct.

After establishing the infection parameters at small scale and the analytical assays, we set out to produce NDV in batch mode in $1 \mathrm{~L}$ stirred tank bioreactors. For NDVGFP, the peak titer produced was $2.37 \pm 0.82 \times 10^{8} \mathrm{TCID}_{50} / \mathrm{mL}$ at $36 \mathrm{hpi}$, which is similar to the highest titer observed in shake flasks $\left(1.07 \pm 0.37 \times 10^{8} \mathrm{TCID}_{50} / \mathrm{mL}\right)$. As for NDV-FLS, the peak production was $3.16 \pm 1.09 \times 10^{7} \mathrm{TCID}_{50} / \mathrm{mL}$ at $48 \mathrm{hpi}$, which is similar to the value at $36 \mathrm{hpi}\left(1.78 \pm 0.62 \times 10^{7} \mathrm{TCID}_{50} / \mathrm{mL}\right)$ when considering the analytical error. This is lower than the highest values achieved with this MOI in shake flasks $\left(9.17 \pm 1.44 \times 10^{7} \mathrm{TCID}_{50} / \mathrm{mL}\right)$, which can occur when scaling up to bioreactors because of differences in stirring and many other factors. Both productions are comparable to the titers produced in embryonated eggs, which is in the order of $10^{8} \mathrm{FFU} / \mathrm{mL}$ [18] and $10^{7} \mathrm{PFU} / \mathrm{mL}$ [47], indicating that the bioreactor-based process developed in this study is a valuable substitute for existing egg-based productions.

Furthermore, process intensification could increase the quantity of infective particles harvested, using technologies such as fed-batch or perfusion [48]. The lower infectious titers observed at later time points in bioreactors and shake flasks suggest that NDV could be a good candidate for production in perfusion mode, as the viruses could be continuously harvested before suffering a loss in infectivity due to temperature and shear stress in the bioreactor.

Therefore, we have successfully developed the upstream process and analytical methods for suspension Vero cell-based production of NDV, using the constructs NDV-GFP and NDV-FLS as models. Future steps include establishing a scalable purification protocol and testing different bioreactor production modes, such as fed-batch and perfusion, to move towards a complete process based on continuous manufacturing.

Supplementary Materials: The following are available online at https:/ / www.mdpi.com/article/10 .3390 /vaccines $9111335 /$ s1, Figure S1: Cytopathic effect seen in TCID $_{50}$ when using different media with Vero cells.

Author Contributions: J.P.C.F.: conceptualization, investigation, formal analysis, writing-original draft preparation, writing - review and editing. O.F.: conceptualization, investigation, writingreview and editing. S.K.: conceptualization, investigation, writing-review and editing. Z.Y.: investigation $\left(\mathrm{TCID}_{50}\right)$. S.D.: investigation (fluorescence microscopy). L.S. and S.K.W.: resources (construction and characterization of NDV-GFP and NDV-FLS). A.A.K.: conceptualization, supervision, funding acquisition, writing - review and editing. All authors have read and agreed to the published version of the manuscript. 
Funding: This research was funded by the National Research Council of Canada (NRC), grant number PR-013.1 for Priority Research on COVID-19. A.A.K. is funded through a Canada Research Chair (CRC-240394). J.P.C.F. received funding from a Mitacs Globalink Graduate Fellowship.

Data Availability Statement: The data presented will be made available through the corresponding author upon request.

Acknowledgments: The authors thank Renald Gilbert and Chun Fang Shen from the National Research Council of Canada (NRC) for providing support with the suspension Vero cell line, and Jacob Yates from University of Guelph for providing support with the NDV constructs.

Conflicts of Interest: The authors declare no conflict of interest.

\section{References}

1. Samaranayake, L.P.; Seneviratne, C.J.; Fakhruddin, K.S. Coronavirus disease 2019 (COVID-19) vaccines: A concise review. Oral Dis. 2021, 1-11. [CrossRef]

2. Kim, S.-H.; Samal, S.K. Newcastle Disease Virus as a Vaccine Vector for Development of Human and Veterinary Vaccines. Viruses 2016, 8, 183. [CrossRef] [PubMed]

3. Ndwandwe, D.; Wiysonge, C.S. COVID-19 vaccines. Curr. Opin. Immunol. 2021, 71, 111-116. [CrossRef]

4. Orenstein, W.A.; Ahmed, R. Simply put: Vaccination saves lives. Proc. Natl. Acad. Sci. USA 2017, 114, 4031-4033. [CrossRef] [PubMed]

5. Tomori, O.; Kolawole, M.O. Ebola virus disease: Current vaccine solutions. Curr. Opin. Immunol. 2021, 71, 27-33. [CrossRef] [PubMed]

6. European Medicines Agency (EMA). Zabdeno Summary of Product Characteristics. Available online: https://www.ema.europa. eu/en/documents/product-information/zabdeno-epar-product-information_en.pdf (accessed on 8 October 2021).

7. European Medicines Agency (EMA). Mvabea Summary of Product Characteristics. Available online: https://www.ema.europa. $\mathrm{eu} / \mathrm{en} /$ documents / product-information/mvabea-epar-product-information_en.pdf (accessed on 8 October 2021).

8. Crommelin, D.J.A.; Volkin, D.B.; Hoogendoorn, K.H.; Lubiniecki, A.S.; Jiskoot, W. The Science is There: Key Considerations for Stabilizing Viral Vector-Based COVID-19 Vaccines. J. Pharm. Sci. 2021, 110, 627-634. [CrossRef]

9. Henao-Restrepo, A.M.; Camacho, A.; Longini, I.M.; Watson, C.H.; Edmunds, W.J.; Egger, M.; Carroll, M.W.; Dean, N.E.; Diatta, I.; Doumbia, M.; et al. Efficacy and effectiveness of an rVSV-vectored vaccine in preventing Ebola virus disease: Final results from the Guinea ring vaccination, open-label, cluster-randomised trial (Ebola Ça Suffit!). Lancet 2017, 389, 505-518. [CrossRef]

10. World Health Organization (WHO). COVID-19 Vaccine Tracker and Landscape. Available online: https://www.who.int/ publications/m/item/draft-landscape-of-covid-19-candidate-vaccines (accessed on 8 October 2021).

11. Mebatsion, T. Introduction to Veterinary Vaccines. In Viral Vectors in Veterinary Vaccine Development: A Textbook; Vanniasinkam, T., Tikoo, S.K., Samal, S.K., Eds.; Springer International Publishing: Cham, Switzerland, 2021; pp. 3-12. [CrossRef]

12. Fernandez-Sainz, I.; Medina, G.N.; Ramirez-Medina, E.; Koster, M.J.; Grubman, M.J.; de los Santos, T. Adenovirus-vectored foot-andmouth disease vaccine confers early and full protection against FMDV O1 Manisa in swine. Virology 2017, 502, 123-132. [CrossRef]

13. Pedersen, L.E.; Patch, J.R.; Kenney, M.; Glabman, R.A.; Nielsen, M.; Jungersen, G.; Buus, S.; Golde, W.T. Expanding specificity of class I restricted CD8+ T cells for viral epitopes following multiple inoculations of swine with a human adenovirus vectored foot-and-mouth disease virus (FMDV) vaccine. Vet. Immunol. Immunopathol. 2016, 181, 59-67. [CrossRef] [PubMed]

14. Adalja, A.A.; Watson, M.; Cicero, A.; Inglesby, T. Vaccine Platforms: State of the Field and Looming Challenges. Johns Hopkins Center for Health Security 2019. Available online: https:/ /www.centerforhealthsecurity.org/our-work/pubs_archive/pubspdfs/2019/190423-OPP-platform-report.pdf (accessed on 15 November 2021).

15. Schirrmacher, V. Immunobiology of Newcastle disease virus and its use for prophylactic vaccination in poultry and as adjuvant for therapeutic vaccination in cancer patients. Int. J. Mol. Sci. 2017, 18, 1103. [CrossRef]

16. Wen, Z.; Zhao, B.; Song, K.; Hu, X.; Chen, W.; Kong, D.; Ge, J.; Bu, Z. Recombinant lentogenic Newcastle disease virus expressing Ebola virus GP infects cells independently of exogenous trypsin and uses macropinocytosis as the major pathway for cell entry. Virol. J. 2013, 10, 331. [CrossRef] [PubMed]

17. Le Ru, A.; Jacob, D.; Transfiguracion, J.; Ansorge, S.; Henry, O.; Kamen, A.A. Scalable production of influenza virus in HEK-293 cells for efficient vaccine manufacturing. Vaccine 2010, 28, 3661-3671. [CrossRef] [PubMed]

18. Sun, W.; Leist, S.R.; McCroskery, S.; Liu, Y.; Slamanig, S.; Oliva, J.; Amanat, F.; Schäfer, A.; Dinnon, K.H.; García-Sastre, A.; et al. Newcastle disease virus (NDV) expressing the spike protein of SARS-CoV-2 as a live virus vaccine candidate. EBioMedicine 2020, 62, 103132. [CrossRef] [PubMed]

19. Milián, E.; Kamen, A.A. Current and emerging cell culture manufacturing technologies for influenza vaccines. BioMed Res. Int. 2015, 2015, 504831. [CrossRef]

20. Kiesslich, S.; Kamen, A.A. Vero cell upstream bioprocess development for the production of viral vectors and vaccines. Biotechnol. Adv. 2020, 44, 107608. [CrossRef]

21. Christie, A.; Henley, S.J.; Mattocks, L.; Fernando, R.; Lansky, A.; Ahmad, F.B.; Adjemian, J.; Anderson, R.N.; Binder, A.M.; Carey, K.; et al. Decreases in COVID-19 Cases, Emergency Department Visits, Hospital Admissions, and Deaths Among Older Adults Following the Introduction of COVID-19 Vaccine-United States, September 6, 2020-May 1, 2021. MMWR Morb. Mortal. Wkly. Rep. 2021, 70, 858-864. [CrossRef] 
22. Khalfaoui, R.; Nammouri, H.; Labidi, O.; Ben Jabeur, S. Is the COVID-19 vaccine effective on the US financial market? Public Health 2021, 198, 177-179. [CrossRef] [PubMed]

23. Rambhia, K.J.; Watson, M.; Sell, T.K.; Waldhorn, R.; Toner, E. Mass Vaccination for the 2009 H1N1 Pandemic: Approaches, Challenges, and Recommendations. Biosecurity Bioterrorism Biodefense Strategy Pract. Sci. 2010, 8, 321-330. [CrossRef] [PubMed]

24. Shen, C.F.; Guilbault, C.; Li, X.; Elahi, S.M.; Ansorge, S.; Kamen, A.; Gilbert, R. Development of suspension adapted Vero cell culture process technology for production of viral vaccines. Vaccine 2019, 37, 6996-7002. [CrossRef]

25. Côté, J.; Garnier, A.; Massie, B.; Kamen, A. Serum-free production of recombinant proteins and adenoviral vectors by $293 \mathrm{SF}-3 \mathrm{~F} 6$ cells. Biotechnol. Bioeng. 1998, 59, 567-575. [CrossRef]

26. Graham, F.L.; Smiley, J.; Russell, W.C.; Nairn, R. Characteristics of a Human Cell Line Transformed by DNA from Human Adenovirus Type 5. J. Gen. Virol. 1977, 36, 59-72. [CrossRef] [PubMed]

27. Warner, B.M.; Santry, L.A.; Leacy, A.; Chan, M.; Pham, P.H.; Vendramelli, R.; Pei, Y.; Tailor, N.; Valcourt, E.; Leung, A.; et al. Intranasal vaccination with a Newcastle disease virus-vectored vaccine protects hamsters from SARS-CoV-2 infection and disease. IScience 2021, 24, 103219. [CrossRef] [PubMed]

28. Spearman, C. The Method of 'Right and Wrong Cases' ('Constant Stimuli') without Gauss's Formulae. Br. J. Psychol. 1904-1920 1908, 2, 227-242. [CrossRef]

29. Kärber, G. Beitrag zur kollektiven Behandlung pharmakologischer Reihenversuche. Naunyn Schmiedebergs Arch. Für Exp. Pathol. Und Pharmakol. 1931, 162, 480-483. [CrossRef]

30. Hierholzer, J.; Killington, R. Virus isolation and quantitation. In Virology Methods Manual; Elsevier: Amsterdam, The Netherlands, 1996; pp. 25-46. [CrossRef]

31. Mo, C.; Yamagata, R.; Pan, A.; Reddy, J.; Hazari, N.; Duke, G. Development of a high-throughput Alamar blue assay for the determination of influenza virus infectious dose, serum antivirus neutralization titer and virus ca/ts phenotype. J. Virol. Methods 2008, 150, 63-69. [CrossRef]

32. Petiot, E.; Cuperlovic-Culf, M.; Shen, C.F.; Kamen, A. Influence of HEK293 metabolism on the production of viral vectors and vaccine. Vaccine 2015, 33, 5974-5981. [CrossRef]

33. Genzel, Y. Designing cell lines for viral vaccine production: Where do we stand? Biotechnol. J. 2015, 10, 728-740. [CrossRef]

34. Kiesslich, S.; Kim, G.N.; Shen, C.F.; Kang, C.Y.; Kamen, A.A. Bioreactor production of rVSV-based vectors in Vero cell suspension cultures. Biotechnol. Bioeng. 2021, 118, 2649-2659. [CrossRef] [PubMed]

35. Sène, M.-A.; Kiesslich, S.; Djambazian, H.; Ragoussis, J.; Xia, Y.; Kamen, A.A. Haplotype-resolved de novo assembly of the Vero cell line genome. NPJ Vaccines 2021, 6, 106. [CrossRef]

36. Yurchenko, K.; Yi, J.; Shestopalov, A. Adaptation of the Newcastle disease virus to cell cultures for enhancing its oncolytic properties. Acta Nat. 2019, 11, 66-73. [CrossRef]

37. Liu, T.; Song, Y.; Yang, Y.; Bu, Y.; Cheng, J.; Zhang, G.; Xue, J. Hemagglutinin-Neuraminidase and fusion genes are determinants of NDV thermostability. Vet. Microbiol. 2019, 228, 53-60. [CrossRef]

38. Al-Ziaydi, A.G.; Al-Shammari, A.M.; Hamzah, M.I. Propagation of oncolytic Newcastle Disease Virus in Embryonated Chicken Eggs and its Research Applications in Cell lines. In Journal of Physics: Conference Series; IOP Publishing: Bristol, UK, $2020 ;$ p. 012129.

39. Nan, F.L.; Zhang, H.; Nan, W.L.; Xie, C.Z.; Ha, Z.; Chen, X.; Xu, X.H.; Qian, J.; Qiu, X.S.; Ge, J.Y.; et al. Lentogenic NDV V protein inhibits IFN responses and represses cell apoptosis. Vet. Microbiol. 2021, 261, 109181. [CrossRef]

40. Genzel, Y.; Dietzsch, C.; Rapp, E.; Schwarzer, J.; Reichl, U. MDCK and Vero cells for influenza virus vaccine production: A one-to-one comparison up to lab-scale bioreactor cultivation. Appl. Microbiol. Biotechnol. 2010, 88, 461-475. [CrossRef]

41. Kaverin, N.V.; Webster, R.G. Impairment of multicycle influenza virus growth in Vero (WHO) cells by loss of trypsin activity. $J$. Virol. 1995, 69, 2700-2703. [CrossRef]

42. Ginting, T.E.; Suryatenggara, J.; Christian, S.; Mathew, G. Proinflammatory response induced by Newcastle disease virus in tumor and normal cells. Oncolytic Virother. 2017, 6, 21-30. [CrossRef]

43. Thompson, C.M.; Petiot, E.; Lennaertz, A.; Henry, O.; Kamen, A.A. Analytical technologies for influenza virus-like particle candidate vaccines: Challenges and emerging approaches. Virol. J. 2013, 10, 141. [CrossRef] [PubMed]

44. Gélinas, J.-F.; Kiesslich, S.; Gilbert, R.; Kamen, A.A. Titration methods for rVSV-based vaccine manufacturing. MethodsX 2020, 7 , 100806. [CrossRef] [PubMed]

45. Rampersad, S.N. Multiple Applications of Alamar Blue as an Indicator of Metabolic Function and Cellular Health in Cell Viability Bioassays. Sensors 2012, 12, 12347-12360. [CrossRef] [PubMed]

46. Vijayakumar, G.; Zamarin, D. Design and Production of Newcastle Disease Virus for Intratumoral Immunomodulation. In Oncolytic Viruses; Engeland, C.E., Ed.; Springer: New York, NY, USA, 2020; pp. 133-154. [CrossRef]

47. Bukreyev, A.; Huang, Z.; Yang, L.; Elankumaran, S.; Claire, M.S.; Murphy, B.R.; Samal, S.K.; Collins, P.L. Recombinant Newcastle Disease Virus Expressing a Foreign Viral Antigen Is Attenuated and Highly Immunogenic in Primates. J. Virol. 2005, 79, 13275-13284. [CrossRef] [PubMed]

48. Silva, C.A.T.; Kamen, A.A.; Henry, O. Recent advances and current challenges in process intensification of cell culture-based influenza virus vaccine manufacturing. Can. J. Chem. Eng. 2021, 99, 2525-2535. [CrossRef] 